\title{
Truncal valve repair in children
}

\author{
Phillip S. Naimo, MD, PhD, , , b,c Edward Buratto, MBBS, PhD, ${ }^{\text {a,c,b }}$ and \\ Igor E. Konstantinov, MD, PhD, FRACS ${ }^{\mathrm{a}, \mathrm{b}, \mathrm{c}, \mathrm{d}}$
}

Truncal valve insufficiency presents significant short- and long-term challenges for congenital cardiac surgeons. Occurring in up to $43 \%$ of patients with truncus arteriosus, truncal valve insufficiency is one of the most important factors influencing the outcomes in these patients. ${ }^{1-9}$ Although an array of surgical techniques has been described, consistently durable results have been difficult to achieve. This is a testament to the fact that the ideal repair technique is yet to be determined. The purpose of this focused review is to highlight recent key publications on the topic.

\section{IMPACT OF TRUNCAL VALVE INSUFFICIENCY ON SURGICAL OUTCOMES}

Mild truncal valve insufficiency is often well tolerated, nonprogressive in the long-term, and does not necessitate truncal valve surgery. ${ }^{1,5,7-13}$ However, moderate or greater truncal valve insufficiency has been associated with greater mortality and often requires truncal valve surgery. $1,3,7,8,13-17$ Several studies have shown that moderate-to-severe truncal valve insufficiency is a risk factor for early truncal valve replacement, 6 early mortality, and, generally, poorer longterm outcomes if not adequately addressed during the initial operation. ${ }^{3,6,13-17}$ Russell and colleagues ${ }^{3}$ reported 23 truncal valve operations in 572 patients operated between 2000 and 2009, concluding that failure to address significant truncal valve insufficiency was associated with poor outcomes. Conversely, Tlaskal and colleagues ${ }^{10}$ determined that persistent moderate insufficiency is usually well tolerated and does not lead to an increase in early mortality, although it was associated with the need for eventual truncal valve replacement. We have recently reported a 20-year overall survival of $79 \%$ in children with no truncal valve insufficiency at the time of initial surgery, $77 \%$ with mild insufficiency, $77 \%$ with moderate insufficiency, but only $22 \%$ at 10 years in those with severe insufficiency. ${ }^{9}$

\footnotetext{
From the a Department of Cardiothoracic Surgery, Royal Children's Hospital; ' Department of Paediatrics, University of Melbourne; ${ }^{\mathrm{c}}$ Heart Research Group, Murdoch Children's Research Institute; and 'Melbourne Children's Centre for Cardiovascular Genomics and Regenerative Medicine, Melbourne, Australia.

Received for publication Aug 21, 2020; revisions received Oct 3, 2020; accepted for publication Oct 7, 2020; available ahead of print Dec 8, 2020.

Address for reprints: Igor E. Konstantinov, MD, PhD, FRACS, Royal Children's Hospital, 50 Flemington Rd, Parkville 3052, Australia (E-mail: igor.konstantinov@ rch.org.au).

J Thorac Cardiovasc Surg 2021;162:1337-42 0022-5223/\$36.00

Crown Copyright $(\subset) 2020$ Published by Elsevier Inc. on behalf of The American Association for Thoracic Surgery

https://doi.org/10.1016/j.jtcvs.2020.10.161
}

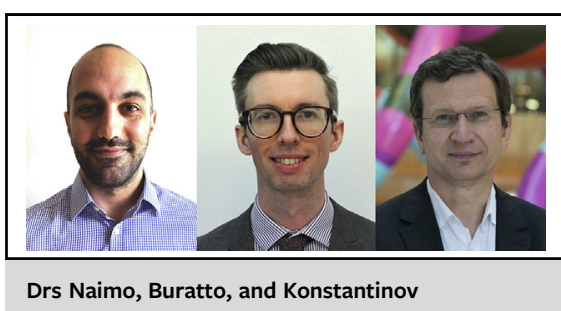

CENTRAL MESSAGE

It appears that reduction of the annulus is essential to improve the durability of truncal valve repair

See Commentaries on pages 1343 and 1345 .

\section{TECHNIQUES OF TRUNCAL VALVE REPAIR}

A number of surgical techniques to repair the truncal valve have been described. Rarely, the truncal valve may be bicuspid and stenotic, requiring commissurotomy. ${ }^{1}$ However, truncal valve insufficiency is more commonly encountered and has been addressed by suturing together partially developed commissures, resuspension of leaflets, resection of redundant portion of leaflets, annuloplasty of commissures and pericardial leaflet extension, and tricuspidization of a quadricuspid valve. Each of these techniques has been reported with varying success. ${ }^{3,5,6,18}$ As the truncal annulus is often large, annular reduction appears to be an efficient way to deal with truncal valve incompetence. Such a reduction of the truncal valve annulus could be achieved by subcommissural (Figure 1, $A$ and $A 1$ ) or circular suture annuloplasty with reduction of sinotubular junction diameter (Figure 1, Al) or by resection of part of the truncal root with complete (Figure 1, $B$ and $B 1$ ) or partial resection of the adjacent cusp (Figure 1, $C$ and $C 1$ ). The resection technique was first described in 1999 by Roger Mee's group ${ }^{19}$ and appears to be effective in neonates and infants with severe truncal valve insufficiency, ${ }^{2,8,20}$ and is more applicable to quadricuspid truncal valves. Although truncal valve repair is generally not durable in the long-term, ${ }^{1}$ it appears that tricuspidization of the truncal valve with ${ }^{8}$ or without ${ }^{21}$ resection of a segment of the truncal root and annular reduction provides the most durable results. Most children who require truncal valve surgery have a quadricuspid truncal valve. ${ }^{1,4,8}$ A detailed video demonstrating the technique of tricuspidization of quadricuspid truncal vale with annular reduction in a neonate has been 


\section{Cusp approximation and suture annuloplasty}
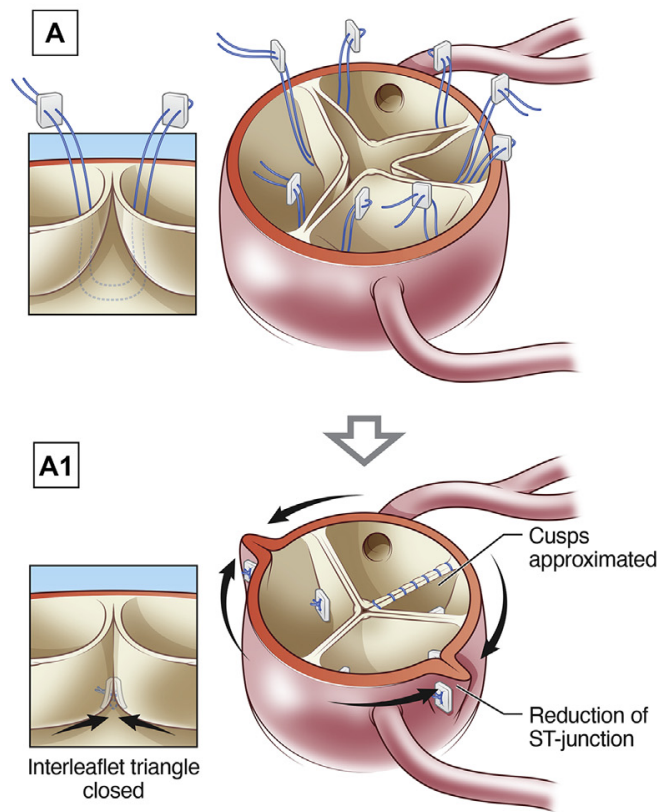

\section{Complete or partial cusp resection with annulus reduction}

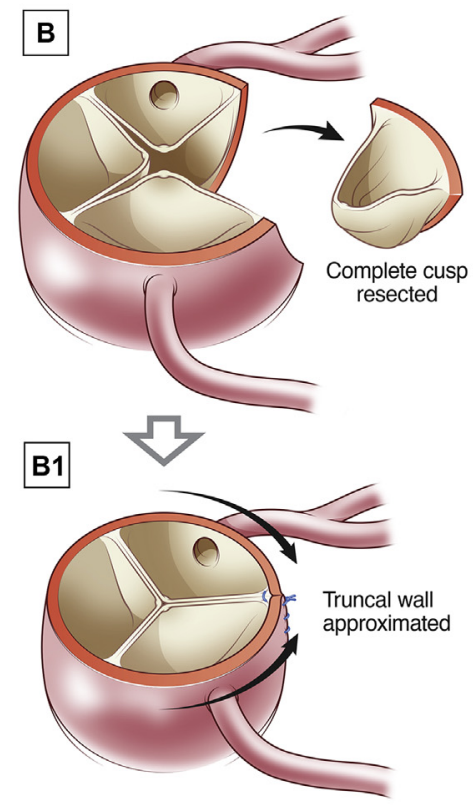

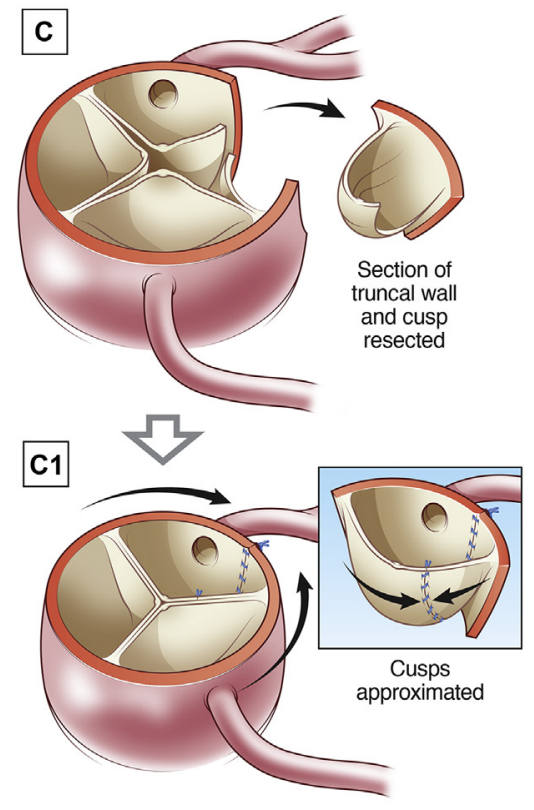

FIGURE 1. Techniques for tricuspidization and annulus reduction in the quadricuspid truncal valve. Tricuspidization can be achieved by suture annuloplasty of the truncal root (A) and approximation of the prolapsing cusp to the adjacent cusp (A1) with obliteration of interleaflet triangles. Alternatively, a cusp can be completely (B) or partially (C) resected, with the root reapproximated (B1 and C1). This achieves both tricuspidization and annular reduction.

previously published. ${ }^{2}$ Because approximately one third of children with truncus arteriosus have quadricuspid truncal valve $^{9,18}$ and approximately one third of children with a quadricuspid valve require valve surgery, ${ }^{8}$ this is a useful technique in armamentarium of congenital heart surgeon.

Unsurprisingly, concomitant truncal valve surgery is more challenging, as it is often required in the youngest and most critically ill children. ${ }^{9}$ However, it is important to repair the truncal valve at this stage, as not addressing severe truncal valve insufficiency has been associated with poor outcomes. ${ }^{1,3,13-17}$

Children with a quadricuspid truncal valve are more likely to undergo truncal valve surgery than those with any other valve morphology. ${ }^{1}$ We have previously reported that patients with a quadricuspid truncal valve and moderate or greater truncal insufficiency were most likely to require truncal valve surgery ${ }^{1}$ and described a tricuspidization technique in a low birth weight neonate in detail. ${ }^{2}$ In contrast, most patients with a quadricuspid truncal valve and mild or less truncal valve insufficiency are free from truncal valve surgery in the long term. Only about $16 \%$ of patients with mild or less insufficiency have progressive truncal valve regurgitation, which may require truncal valve surgery. ${ }^{8,9}$ The preferred method of repair in those with moderate or greater insufficiency that appears to give best long-term results is tricuspidization of the quadricuspid valve with reduction of the annulus. ${ }^{8,9,21}$ In children with significant truncal valve insufficiency, the large diameter of the annulus and relative deficiency of valvar tissue to cover truncal orifice often necessitates reduction of the truncal valve annulus. This can be achieved by resection of a cusp extending onto the annulus. ${ }^{2,19}$ Such resection leading to tricuspidization appears to be more durable than any other methods of repair. ${ }^{8}$ Truspidization with basepreserving cusp extension with autologous pericardium in infants has been recently described, ${ }^{22}$ yet long-term outcomes of such a repair remain to be seen. The importance of correcting significant truncal valve insufficiency cannot be overemphasized. In a contemporary multicenter study, $20 \%$ of children who underwent repair of truncus arteriosus experienced major adverse cardiac events. ${ }^{23}$ However, such events did not occur more frequently in children, who underwent concomitant surgical intervention on the truncal valves. In contrast, residual significant truncal valve insufficiency, which required an early reoperation, had uniformly poor outcomes. ${ }^{4}$ Furthermore, children with significant truncal valve insufficiency and interrupted aortic arch have particularly poor outcomes. ${ }^{4,24}$

\section{RESULTS}

Generally, repair of truncal valve is associated with poor durability (Table 1). ${ }^{5,21}$ Kaza and colleagues ${ }^{5}$ in 2010 showed that in 14 patients who underwent truncal valve repair by leaflet approximation and suture annuloplasty, freedom from truncal valve reintervention was $70 \%$ at 5 years and $50 \%$ at 7 years. We have recently reported a 
TABLE 1. Outcomes of concomitant repair of truncus arteriosus and truncal valve in neonates and infants

\begin{tabular}{lccccccccc}
\hline \multicolumn{1}{c}{ Study } & Study period & $\mathbf{n}$ & $\begin{array}{c}\text { Median } \\
\text { age }\end{array}$ & Repair & Replacement & $\begin{array}{c}\text { Follow-up } \\
\text { (mean y) }\end{array}$ & $\begin{array}{c}\text { Early } \\
\text { deaths }\end{array}$ & $\begin{array}{c}\text { Truncal valve } \\
\text { Late deaths } \\
\text { reoperations }\end{array}$ \\
\hline Black, 2002 & $1996-1998$ & 5 & Neonates & $80 \%(4 / 5)$ & $20 \%(1 / 5)$ & NR & $0 \%$ & $20 \%(1 / 5)$ & NR \\
Henaine et al, 2008 & $1986-2003$ & 9 & $35 \mathrm{~d}$ & $67 \%(6 / 9)$ & $33 \%(3 / 9)$ & 8.1 & $44 \%(4 / 9)$ & $20 \%(1 / 5)$ & $60 \%(3 / 5)$ \\
\hline Kaza et al, 2010 & $1995-2008$ & 17 & $24 \mathrm{~d}$ & $100 \%(17 / 17)$ & $0 \%$ & 2 & $0 \%$ & $6 \%(1 / 17)$ & $29 \%(5 / 17)$ \\
Russell et al, $2012^{3}$ & $2000-2009$ & 23 & $12 \mathrm{~d}$ & $96 \%(22 / 23)$ & $4 \%(1 / 23)$ & $\mathrm{NR}$ & $26 \%(6 / 23)$ & $\mathrm{NR}$ & $\mathrm{NR}$ \\
Russell et al, $2012^{4}$ & $1979-2011$ & 5 & $8 \mathrm{~d}$ & $100 \%(5 / 5)$ & $0 \%$ & 5.5 & $40 \%(2 / 5)$ & $0 \%$ & $33 \%(1 / 3)$ \\
\hline Myers et al, $2013^{21}$ & $1997-2012$ & 13 & $\mathrm{NR}$ & $100 \%(11 / 11)$ & $0 \%$ & 3.2 & $27 \%(3 / 11)$ & $\mathrm{NR}$ & $88 \%(7 / 8)$ \\
\hline Naimo et al, $2018^{1}$ & $1979-2016$ & 21 & $52 \mathrm{~d}$ & $95 \%(20 / 21)$ & $5 \%(1 / 21)$ & 18 & $19 \%(4 / 21)$ & $11 \%(2 / 19)$ & $68 \%(13 / 19)$ \\
\hline
\end{tabular}

$N R$, Not reported.

freedom from truncal valve reoperation of $65 \%$ at 5 years, $51 \%$ at 10 years, and $26 \%$ at 20 years after concomitant truncal valve repair. ${ }^{1}$ Concomitant truncal valve surgery has been shown to be a risk factor for late truncal valve surgery. ${ }^{7}$

We have previously reported that most patients $(57 \%, 12 /$ 21) who required concomitant truncal valve repair had a quadricuspid valve. ${ }^{1}$ Furthermore, most $(79 \%, 15 / 19)$ patients who had moderate and severe truncal valve insufficiency had a quadricuspid truncal valve. ${ }^{1}$ Freedom from truncal valve reoperation was $64 \%$ at 10 years after tricuspidization of the quadricuspid truncal valve. ${ }^{8}$ In fact, freedom from truncal valve reoperation after tricuspidization was superior to truncal valve replacement in children younger than 6 years of age in whom a mechanical prosthesis may not be feasible. ${ }^{8}$ Importantly, freedom from reoperation in patients who underwent concomitant tricuspidization was $64 \%$ at 10 years compared with $0 \%$ at 6 years in patients who underwent concomitant truncal valve repair by nontricuspidization. ${ }^{8}$ Similarly, Myers and colleagues $^{21}$ reported tricuspidization methods of truncal valve repair tended to improve freedom from reoperation on the truncal valve.

Replacement with a large prosthesis may not be feasible in younger children, and avoidance of a mechanical prosthesis may obviate the need for life-long anticoagulation. Thus, tricuspidization of the quadricuspid truncal valve is desirable whenever possible. While the durability of repair remains questionable, it is preferable over replacement, particularly during the neonatal period.

\section{CONCLUSIONS}

Concomitant truncal valve surgery is most commonly required for quadricuspid truncal valve. Overall, truncal valve repair is not durable. It appears that tricuspidization and annular reduction with complete or partial resection of one cusp give most durable result.

\section{Conflict of Interest Statement}

The authors reported no conflicts of interest.
The Journal policy requires editors and reviewers to disclose conflicts of interest and to decline handling or reviewing manuscripts for which they may have a conflict of interest. The editors and reviewers of this article have no conflicts of interest.

\section{References}

1. Naimo PS, Fricke TA, d'Udekem Y, Brink J, Weintraub RG, Brizard CP, et al. Impact of truncal valve insufficiency on the outcomes of truncus arteriosus repair. Eur J Cardiothorac Surg. 2018;54:524-31.

2. Konstantinov IE, Perrier SL, Naimo PS, d'Udekem Y. Neonatal quadricuspid truncal valve repair with left coronary artery unroofing. J Thorac Cardiovasc Surg. 2019;157:710-1.

3. Russell HM, Pasquali SK, Jacobs JP, Jacobs ML, O’Brien SM, Mavroudis C, et al. Outcomes of repair of common arterial trunk with truncal valve surgery: a review of the Society of Thoracic Surgeons congenital heart surgery database. Ann Thorac Surg. 2012;93:164-9.

4. Russell HM, Mavroudis CD, Backer CL, Mavroudis C. Long-term follow-up after truncal valve repair. Cardiol Young. 2012;22:718-23.

5. Kaza AK, Burch PT, Pinto N, Minich LL, Tani LY, Hawkins JA. Durability of truncal valve repair. Ann Thorac Surg. 2010;90:1307-12.

6. Henaine R, Azarnoush K, Belli E, Capderou A, Roussin R, Planché C, et al. Fate of the truncal valve in truncus arteriosus. Ann Thorac Surg. 2008;85:172-8.

7. Naimo PS, Fricke TA, Yong MS, d'Udekem Y, Kelly A, Radford DJ, et al. Outcomes of truncus arteriosus repair in children: 35 years of experience from a single institution. Semin Thorac Cardiovasc Surg. 2016;28:500-11.

8. Naimo PS, Fricke TA, Lee MGY, d'Udekem Y, Brink J, Brizard CP, et al. The quadricuspid truncal valve: surgical management and outcomes. J Thorac Cardiovasc Surg. November 4, 2020 [E-pub ahead of print].

9. Naimo PS, Bell D, Fricke TA, d'Udekem Y, Brizard CP, Alphonso N, et al. Truncus arteriosus repair: a 40-year multi-center perspective. J Thorac Cardiovasc Surg. May 15, 2020 [E-pub ahead of print].

10. Tlaskal T, Chaloupecky V, Hucin B, Gebauer R, Krupickova S, Reich O, et al Long-term results after correction of persistent truncus arteriosus in 83 patients. Eur J Cardiothorac Surg. 2010;37:1278-84.

11. Hawkins JA, Kaza AK, Burch PT, Lambert LM, Holubkov R, Witte MK. Simple versus complex truncus arteriosus neutralization of risk but with increased resource utilization. World J Pediatr Congenit Heart Surg. 2010;1:285-91.

12. Thompson LD, McElhinney DB, Reddy VM, Petrossian E, Silverman NH, Hanley FL. Neonatal repair of truncus arteriosus: continuing improvement in outcomes. Ann Thorac Surg. 2001;72:391-5.

13. Black MD. Truncal valve repair in common arterial trunk. Prog Pediatr Cardiol. 2002;15:59-63.

14. Di Donato R, Fyfe D, Puga F, Danielson G, Ritter D, Edwards W, et al. Fifteenyear experience with surgical repair of truncus arteriosus. J Thorac Cardiovasc Surg. 1985;89:414.

15. Hanley F, Heinemann M, Jonas R, Mayer J Jr, Cook N, Wessel D, et al. Repair of truncus arteriosus in the neonate. J Thorac Cardiovasc Surg. 1993;105:1047-56.

16. Rajasinghe HA, McElhinney DB, Reddy VM, Mora BN, Hanley FL. Long-term follow-up of truncus arteriosus repaired in infancy: a twenty-year experience. $J$ Thorac Cardiovasc Surg. 1997;113:869-79. 
17. Pearl JM, Laks H, Drinkwater DC, Milgalter E, Giacobetti F, George B, et al. Repair of truncus arteriosus in infancy. Ann Thorac Surg. 1991;52:780-6.

18. Mavroudis C, Backer CL. Surgical management of severe truncal insufficiency: experience with truncal valve remodeling techniques. Ann Thorac Surg. 2001;72: 396-400.

19. Imamura M, Drummond-Webb JJ, Sarris GE, Mee RB. Improving early and intermediate results of truncus arteriosus repair: a new technique of truncal valve repair. Ann Thorac Surg. 1999;67:1142-6.

20. Wei LY, Chen YS, Chiu IS, Huang SC. Repair of a quadricuspid truncal valve by tricuspidization and reconstruction of right ventricular outflow tract with the excised truncal cusp. J Thorac Cardiovasc Surg. 2018;155: 1186-9.

21. Myers PO, Bautista-Hernandez V, Pedro J, Marx GR, Mayer JE, Pigula FA, et al. Surgical repair of truncal valve regurgitation. Eur J Cardiothorac Surg. 2013;44: 813-20.
22. Fujita S, Yamagishi M, Miyazaki T, Yaku H. Leaflet-base-preserving truncal vale repair with ethanol-treated autologous pericardium. J Thorac Cardiovasc Surg. 2019;157:1114-6.

23. Mastropietro CW, Amula V, Sassalos P, Buckley JR, Smerling AJ, Iliopoulos I, et al. Characteristics and operative outcomes for children undergoing repair of truncus arteriosus: a contemporary multicenter analysis. J Thorac Cardiovasc Surg. 2019;157:2386-98.

24. Konstantinov IE, Karamlou T, Blackstone EH, Mosca RS, Lofland GK, Caldarone CA, et al. Truncus arteriosus associated with interrupted aortic arch in 50 neonates: a Congenital Heart Surgeons Society study. Ann Thorac Surg. 2006;81:214-22.

Key Words: truncal valve repair, truncus arteriosus, surgery 


\section{Truncal valve repair in children: Recent articles from AATS Journals}

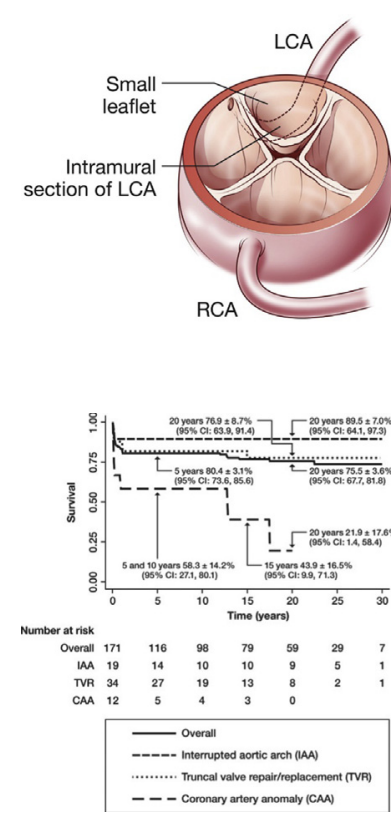

Tricuspidization

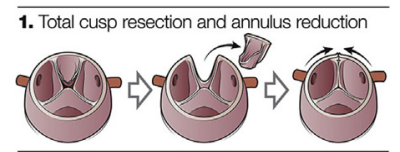

2. Cusp reconstruction and annulus reduction

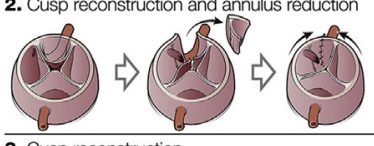

3. Cusp reconstruction
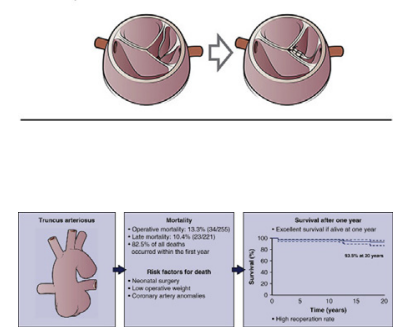

JTCVS
JTCVS: Neonatal quadricuspid truncal valve repair with left coronary artery unroofing. Konstantinov IE, Perrier SL, Naimo PS, d'Udekem Y. J Thorac Cardiovasc Surg. 2019;157(2): 710-711.

Commentary: A coronary and a cusp. Dentel JN, Walters HL $3^{\text {rd }}$. J Thorac Cardiovasc Surg. 2019; 157(2):712-713.

STCVS: Outcomes of truncus arteriosus repair in children: 35 years of experience from a single institution. Naimo PS, Fricke TA, Yong MS, d'Udekem Y, Kelly A, Radford DJ, Bullock A, Weintraub RG, Brizard CP, Konstantinov IE. Semin Thorac Cardiovasc Surg. 2016; 28(2):500-511.

Commentary: The initial glimpse at long-term outcomes following the repair of truncus arteriosus. Alfieris GM, Swartz MF. Semin Thorac Cardiovasc Surg. 2016;28(2):512-513.

JTCVS: The quadricuspid truncal valve: Surgical management and outcomes. Naimo PS, Fricke TA, Lee MGY, d'Udekem Y, Brink J, Brizard CP, Konstantinov IE. J Thorac CardiovasC Surg. 2020 [In press].

Commentary: Truncal root remodeling: A useful technique that can be translated to other lesions? Kaza AK. J Thorac Cardiovasc Surg. 2020 [In press].

Commentary: This looks like a great hammer... which nails should we pound? Kirshbom PM. J Thorac Cardiovasc Surg. 2020 [In press].

JTCVS: Truncus arteriosus repair: A 40-year multicenter perspective. Naimo PS, Bell D, Fricke TA, d'Udekem Y, Brizard CP, Alphonso N, Konstantinov IE. J Thorac Cardiovasc Surg. 2020 [In press].

Commentary: Truncus among us. Mascio CE. J Thorac Cardiovasc Surg. 2020 [In press] Commentary: Outcomes of truncus arteriosus repair: Insights from time and numbers. Hornik CP. J Thorac Cardiovasc Surg. 2020 [In press].

JTCVS: Fifteen-year experience with surgical repair of truncus arteriosus. Di Donato RM, Fyfe DA, Puga FJ, Danielson GK, Ritter DG, Edwards WD, McGoon DC. J Thorac Cardiovasc Surg. 1985;89(3):414-22. 


\section{JTCVS}

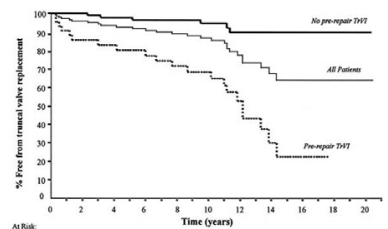

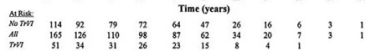
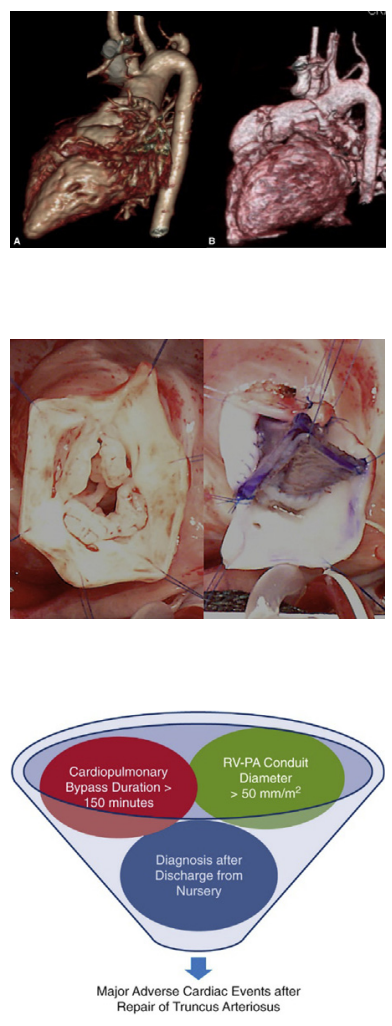

JTCVS: Characteristics and operative outcomes for children undergoing repair of truncus arteriosus: A contemporary multicenter analysis. Mastropietro CW, Amula V, Sassalos P, Buckley JR, Smerling AJ, lliopoulos I, Riley CM, Jennings A, Cashen K, Narasimhulu SS, Narayana Gowda KM, Bakar AM, Wilhelm M, Badheka A, Moser EAS, Costello JM; Collaborative Research in Pediatric Cardiac Intensive Care Investigators. J Thorac Cardiovasc Surg. 2019;157(6):2386-2398.e4.

Commentary: Assessing risk factors after truncus arteriosus repair-The devil is in the details. Alsoufi B. J Thorac Cardiovasc Surg. 2019;157(6)2399-2401.

Commentary: Clear as mud: Truncus arteriosus and major adverse cardiac events. Karamlou T. J Thorac Cardiovasc Surg. 2019;157(6)2402-2403.

Commentary: Timing (and size) is everything? Husain SA. J Thorac Cardiovasc Surg. 2019;157(6) 2404-2405. 